Article

\title{
Evaluating the Suitability of a Combine Harvester Equipped with the Sunflower Header to Harvest Cardoon Seeds: A Case Study in Central Italy
}

\author{
Francesco Latterini ${ }^{1}\left(\mathbb{D}\right.$, , Walter Stefanoni ${ }^{1, * \mathbb{D}}$, Simone Sebastiano ${ }^{2}$, Gian Maria Baldi ${ }^{3}$ \\ and Luigi Pari ${ }^{1}$ (D) \\ 1 Consiglio per la Ricerca in Agricoltura e 1'Analisi dell'Economia Agraria (CREA), Centro di Ricerca \\ Ingegneria e Trasformazioni Agroalimentari, Via della Pascolare 16, 00015 Monterotondo, Italy; \\ francesco.latterini@crea.gov.it (F.L.); luigi.pari@crea.gov.it (L.P.) \\ 2 Maccarese SPA, Società Agricola, Viale Maria 423, 00057 Fiumicino, Italy; \\ simonesebastiano@maccaresespa.com \\ 3 Novamont SPA, Via G. Fauser 8, 28100 Novara, Italy; gianmaria.baldi@novamont.com \\ * Correspondence: walter.stefanoni@crea.gov.it
}

Received: 30 October 2020; Accepted: 12 December 2020; Published: 16 December 2020

\begin{abstract}
Cardoon seeds have been proved to thrive in the Mediterranean region, even under low input management and its biomass is suitable for several food and industrial uses. Despite that, a proper value chain has not been set properly and uncertainty still lays among producers and industries, particularly concerning the harvesting stage. The present study supports, via field trials, the hypothesis that cardoon seeds can be harvested using a conventional combine harvester equipped with the sunflower header. Theoretical field capacity (TFC), effective field capacity (EFC), and field efficiency (FE) were $2.36 \mathrm{ha} \mathrm{h}^{-1}, 2.05 \mathrm{ha} \mathrm{h}^{-1}$, and $1.82 \mathrm{Mg} \mathrm{h}^{-1}$, respectively, while harvesting costs were calculated as $69.52 € \mathrm{ha}^{-1}$. Seed loss was only $3.2 \% \mathrm{w} / \mathrm{w}$ of the potential seed yield. The machinery's performance, costs, and seed loss are comparable with sunflower harvesting, underlying the possibility to use the available technology directly to harvest cardoon seeds.
\end{abstract}

Keywords: value chain; work productivity; harvesting costs; seed loss; marginal lands

\section{Introduction}

The continuous increasing interest of the biorefinery industries in the exploitation of bioresources stimulates the agricultural sector to broaden the scenario of the available feedstocks [1]. Biorefineries usually rely on agricultural residues or raw materials to produce either thermal energy or biodegradable monomers for further industrial applications [2]. Such a new sustainable exploitation of natural source is strongly encouraged by the UE's circular economy policy, at different levels, inviting European stakeholders to endorse this Action Plan actively [3]. However, the cultivation of energy and industrial crops arises concerns regarding the proper land use, since the competition for food production is unavoidable [4]. A possible alternative, may be offered by rustic species that can grow and thrive on low productive soils, or even on marginal lands which are unsuitable for food crops cultivation [5-7]. Additionally, the cultivation of rustic species on marginal lands or less-productive ones can also improve the wellness of local citizens, since it could generate job opportunities. This, would involve the contribution of several stakeholders, such as farmers, contractors, and the transportation sector [8].

Among the crops suitable for cultivation on marginal lands, cardoon (Cynara cardunculus L.) is a perennial multipurpose species that exhibits a good adaptation to drought environments similar to the Mediterranean region [9-12]. Cardoon seeds have been extensively studied as alternative crops 
under several UE Programmes [13], highlighting the profound interest of the scientific community to promote the interesting features of this species.

Good biomass and seed yields were obtained by low input management, thanks to the particular adaptability of $C$. cardunculus to the Mediterranean environment. This is mainly related to its autumn-spring growth season, from September (emergence) to July (seed maturity), to the feasibility to rain fed cultivation, and to the capability of accumulating sugar, in particular inulin, in the roots [14].

The proposal of using cardoon seeds for oil production arose from the fact that the species is botanically related to other oil crops such as sunflower of safflower, which presents oil with similar characteristics to the cardoon oil [15]. Moreover, cardoon oil extracted from seeds, is particularly suitable for biodiesel and biopolymers production [16-19].

The cardoon seeds establishment is accomplished either by seedling or by planting. Seedling is the most adopted strategy although a higher variability is experienced among plants [20-24]. Seedling takes place in the fall or spring season, seeds are applied at the rate of 3-4 kg ha ${ }^{-1}$ up to $4.6 \mathrm{~kg} \mathrm{ha}^{-1}$, in the case of plant density as high as 110,000 plants per hectare [25]. While, the harvest of the aboveground biomass takes place in the summer, using different machines according to the purpose of cultivation, moisture content, and the available fleet at the farm. The whole biomass can be harvested using a forage harvester or biomass harvester-baler [13], while seeds have to be harvested using a combine harvester [26]. The first attempts of Cynara seeds mechanical harvesting are dated back to the 90s, but machines could not cope with the high quantity of pappi released by the capitula during harvesting. Major concerns arose regarding the safety and feasibility of such an operation [27]. However, later studies conducted by Pari et al. [28-31] proposed alternative strategies to pursue the problems: A dedicated header for Cynara seeds harvesting capable of reducing the seed loss, a flexible header for allowing harvesting on stony soils, and finally, a wetting system to reduce as much as possible the pappi dispersal [32]. The development of dedicated headers permitted the dramatic reduction of the seed loss, although it could represent a considerable investment for the contractor, which could not be satisfactorily paid off considering the currently lack of a proper value chain.

Therefore, it is important to investigate the advantages and disadvantages of using non-specific equipment for Cynara seeds harvesting. Small farms and contractors' fleets are usually limited in number due to the high purchase costs of the machineries. Therefore, the possibility to exploit a conventional combine harvester equipped for sunflower (Helianthus annuus L.) seeds harvesting even for Cynara seeds harvesting, would represent an advantage for small scale enterprises. The present study aims to provide them with technical data collected, in a large scale trial, regarding the performance, costs, and seed loss experienced in Cynara seeds mechanical harvesting, which is performed with a combine harvester equipped with the sunflower header.

\section{Materials and Methods}

\subsection{Study Area}

Tests of mechanical harvesting of cardoon seeds were carried out on a field located in Maccarese (Fiumicino, Lazio, Italy) (WGS84-UTM33T coordinate 271167 E, 4633933 N; 0 m a.s.l.) in August 2020. The overall surface of the field was 18.32 ha, but the effectively sown area corresponded to $17.67 \mathrm{ha}$, considering that the presence within the field of ditches was not affected by sowing (Figure 1). The nutritional values of the soil were not investigated, while the texture was classified as silty clay loam soil. The previous crop was Triticale. 


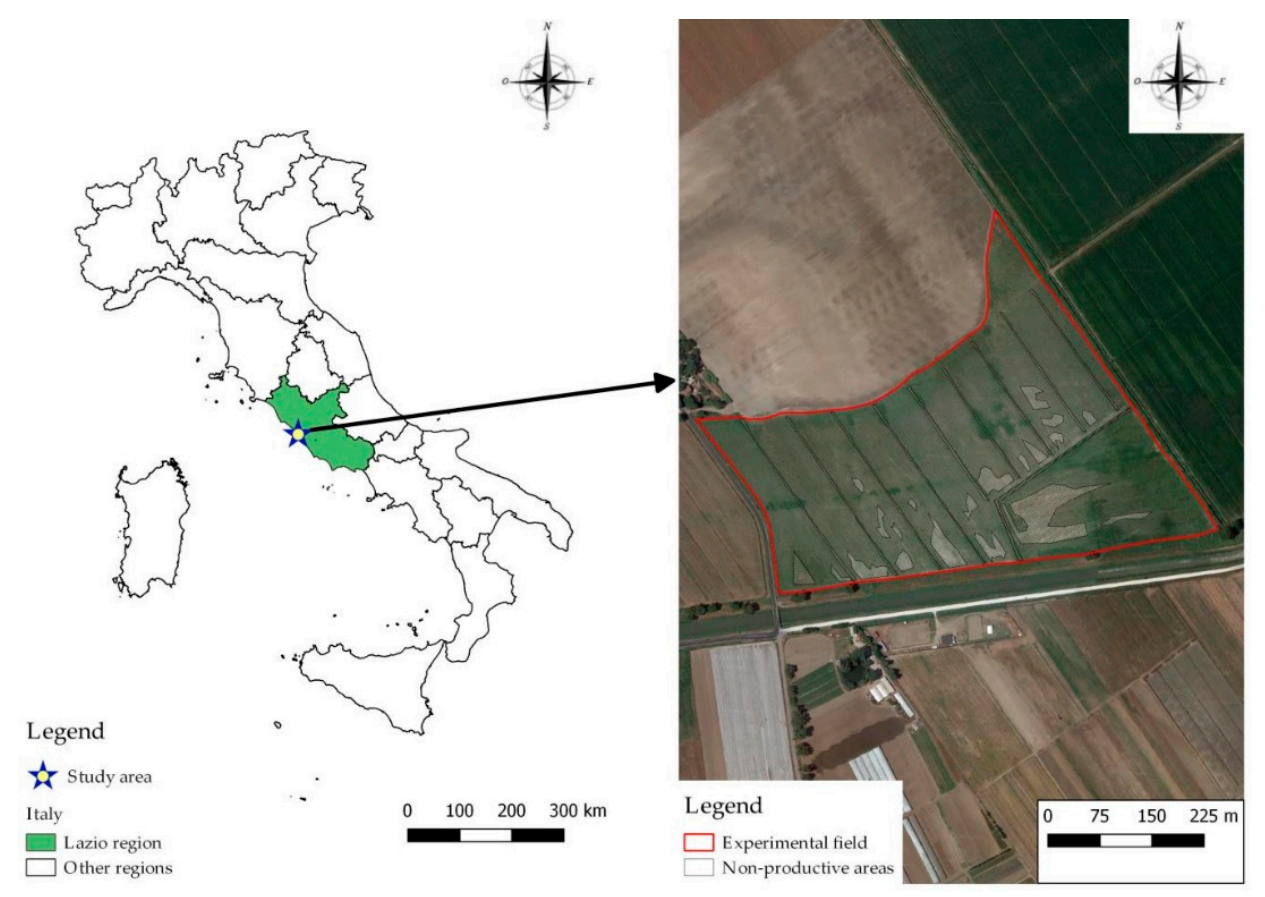

Figure 1. Experimental field location.

Pre-seeding operations, performed in 2018, consisted of a previous subsoiling at a $30 \mathrm{~cm}$ depth, followed by harrowing through a rotative harrow. Excessive rainfall during autumn 2018 did not allow for seeding in the optimal time for cardoon seeds, i.e., November. Therefore, seeding was performed in February 2019, through a pneumatic seed drill applying $3 \mathrm{~kg} \mathrm{ha}^{-1}$ of the seed (rows spacing $50 \times 75 \mathrm{~cm}$ ). The presence of water stagnation in some parts of the field led to an inhomogeneous seed emergence.

In March 2019, weeding through the appliance of "Pendimetalin" was applied to avoid weeds emergence. It is important to underline the absence of registered agrochemicals for cardoon cultivation.

Considering the long-lasting high moisture of the soil, in May 2019, a manual extirpation of weeds was needed. Subsequently, on the first half of July 2019, the overall aerial biomass was chopped, forcing the plant to re-sprout.

In February 2020, the fertilization operation was carried out, with the appliance of $160 \mathrm{~kg} \mathrm{ha}^{-1}$ of a slow-release nitrogen fertilizer, corresponding to $73 \mathrm{~N}$-unit per hectare. After this, as mentioned above, seed harvesting took place in August 2020.

The total rainfall from chopping to harvesting was $583 \mathrm{~mm} \mathrm{ha}^{-1}$, with periods of increased precipitation in November and December 2019 (326 mm ha-1).

It is important to underline that, even if the field shows a negligible value of slope and the total absence of rocks, it can be considered marginal, taking into account the context in which it is located. Indeed, the main crops of the area of Maccarese consist of potatoes and carrots. The soil texture of the field, which shows an excessive percentage of clay for the cultivation of the abovementioned vegetables, as well as the frequent water stagnation in some zones, make it practically impossible to cultivate this field with the typical crops in the area. Particularly, as a consequence of water stagnation, cardoon seeds were not able to grow in some of the field zones. Therefore, of the 17.67 ha of the sown surface, only 16.05 ha showed, in August 2020, the presence of cardoon plants.

\subsection{Pre-Harvest Tests}

Prior to the harvesting operation, 10 sample plots of $9 \mathrm{~m}^{2}$ each $(3 \times 3 \mathrm{~m})$ were randomly selected to estimate the amount of the overall aerial biomass. Plants were cut at the ground level and brought outside the field to be counted and measured in both weight and height. The capitula from each sample plot were manually removed, counted, put in sealed bags, and shipped to the laboratory of 
Research Centre for Engineering and Agro-Food Processing (CREA-IT). The same was applied for five plants from each sample plot.

In the laboratory, a stationary thresher (PLOT 2375 Thresher, Cicoria Company, San Gervasio, Italy) was used to thresh the capitula and collect the seeds.

In this way, it was possible to evaluate the theoretical yield of the seed, dry weight (DW), and moisture content.

\subsection{Combine Harvester}

A local contractor enterprise provided the combine harvester, a FiatAgri L624 (Figure 2) equipped with a conventional cleaning shoe and a $4.8 \mathrm{~m}$ wide Laverda $\mathrm{C} 480$ header, modified with a Zaffrani sunflower kit [33]. The machine was driven by a $176 \mathrm{~kW}$ diesel engine. The applied setting, which was kept constant throughout the test, was as follows: Concave clearance of $23.7 \mathrm{~mm}$, thresher speed of $800 \mathrm{rpm}$, fan speed of $420 \mathrm{rpm}$, upper sieve clearance of $5 \mathrm{~mm}$, and lower sieve clearance of $4 \mathrm{~mm}$.

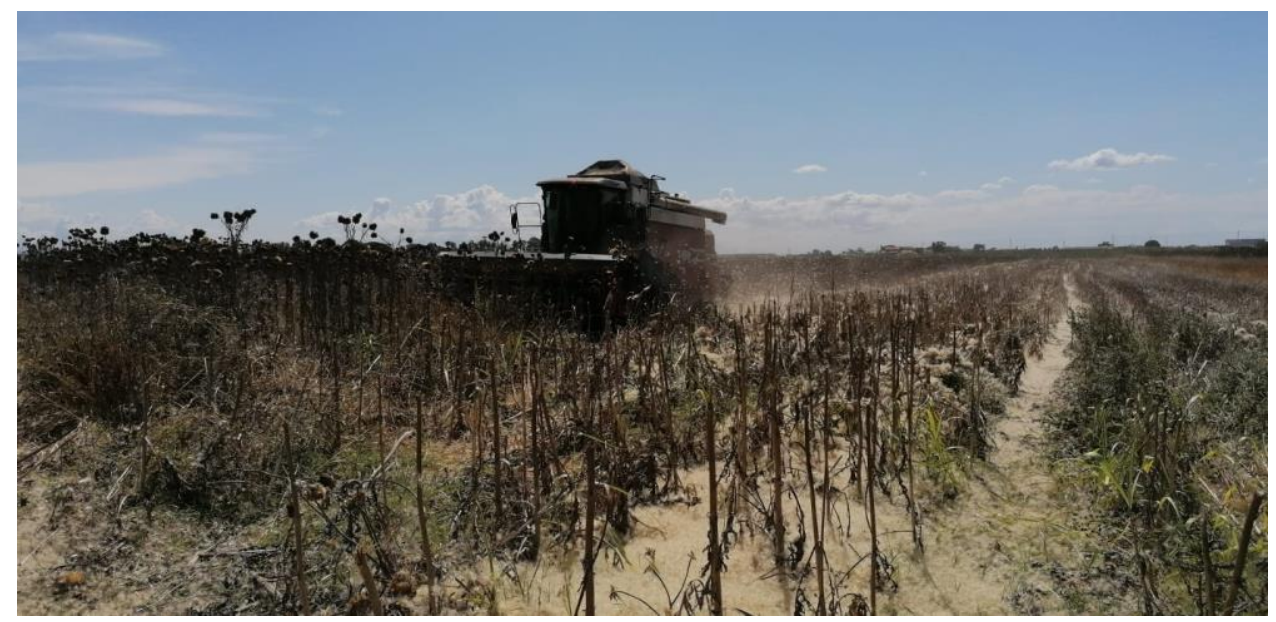

Figure 2. FiatAgri L624 combine harvester at work.

\subsection{Evaluation of the Harvesting Performance}

Twenty-three sample plots were randomly chosen within the field to evaluate the working performance of the combine harvester. The surface of each plot ranged between 959 to $1330 \mathrm{~m}^{2}$. Working times were estimated according to Reith et al. (2017) [34] with a hand chronometer Pro touch. In particular, the working times were divided into: Effective working time, maneuvers time, avoidable delay time, unavoidable delay time, and accessory time.

Measuring the working speed allowed estimating the theoretical field capacity (TFC, ha $\mathrm{h}^{-1}$ ), the effective field capacity $\left(\mathrm{EFC}, \mathrm{ha} \mathrm{h}^{-1}\right)$, and material capacity $\left(\mathrm{MC}, \mathrm{Mg} \mathrm{h}^{-1}\right.$ ), namely:

- $\quad$ TFC: Working speed $\times$ cutting bar width;

- EFC: Harvested surface/working times (effective working time + maneuvers time, avoidable delay time + unavoidable delay time + accessory time);

- MC: Harvested seeds/working times (effective working time + maneuvers time, avoidable delay time + unavoidable delay time + accessory time).

It is important to underline that the material capacity referred to the seed collected in relation to the effectively grown surface of $16.05 \mathrm{ha}$. The ratio between EFC and TFC is named field efficiency (FE). The time needed to discharge the combine harvester was recorded as the accessory time. After the harvesting operation, the material collected was discharged onto a trailer and weighed to determine the seed yield at the farm scale. A sample of the collected material was taken and put in the sealed bag for an evaluation of the moisture content and the 1000-seeds weight. The dry weight and moisture content were assessed according to the EN ISO 18134-2:2017 standard [35]. For the seeds, the same 
procedure was applied to evaluate the dry weight and moisture content of both leaves and stalks. The collected bulk density and 1000 seeds-weight were also measured. The seeds bulk density $\left(\mathrm{Mg} \mathrm{m}^{-3}\right)$ was assessed according to ISO 17828:2015 [36] in 10 randomly selected samples taken from the trailer, in which the seeds were discharged by the combine harvester.

\subsection{Estimation of Harvesting Costs}

An interview with the contractor allowed identifying the purchase and operating costs of the combine harvester, while the performance of the machine was gained from the results of the field tests and used as input data. Finally, the standard values for calculation were taken from the CRPA (Research Centre on Animal productions) methodology [37], as applied in previous studies on a similar topic [38]. The hourly cost of the combine harvester was estimated taking into account the market value of the agricultural machinery. The price of the machine was discounted to 2019, through the application of a lending rate of $3 \%$ provided by the Banca d' Italia Institute [39]. Fuel consumption was measured by filling the tank before starting the harvesting operation, then the tank was filled again at the end of the operation. The fuel used was recorded and used for the assessment of fuel consumption. Consumption of the lubricant was calculated according to the ASAE standard D497.4 [40]. The applied parameters for the economic evaluation are reported in Table 1.

Table 1. Parameters and values used for the economic evaluation.

\begin{tabular}{cccc}
\hline & Parameter & Measure Unit & Value \\
\hline Machine & Power & $\mathrm{kW}$ & 176 \\
\hline Financial costs & Investment & $€$ & 250,000 \\
& Service life & $\mathrm{yr}$ & 10 \\
& Service life & $\mathrm{h}$ & 3000 \\
Resale & $\%$ & 19.00 \\
& Resale & $€$ & $47,500.00$ \\
& Depreciation & $€$ & $202,500.00$ \\
Fixed costs & Interest rate & $\mathrm{h} \mathrm{yr}$ & 312 \\
& Ownership costs & $€$ & 3.00 \\
\hline Interests & $€ \mathrm{yr}^{-1}$ & $20,250.00$ \\
& Machine shelter & $\mathrm{mr}^{-1}$ & 4462.50 \\
& Value of the shelter & $€ \mathrm{~m}^{-2}$ & 22.08 \\
& Value of the shelter & $€ \mathrm{yr}^{-1}$ & 400.00 \\
& Insurance & $€ \mathrm{yr}^{-1}$ & 62.16 \\
& Repair factor & $\%$ & 40 \\
\hline Variable costs & Repairs and maintenance & $€ \mathrm{~h}^{-1}$ & 34.67 \\
& Fuel cost & $€ \mathrm{l}^{-1}$ & 0.57 \\
& Fuel consumption & $1 \mathrm{~h}^{-1}$ & 25.00 \\
& Fuel cost & $€ \mathrm{~h}^{-1}$ & 14.25 \\
& Lubricant cost & $€ \mathrm{l}^{-1}$ & 3.03 \\
& Lubricant consumption & $1 \mathrm{~h}^{-1}$ & 0.32 \\
& Lubricant cost & $€ \mathrm{~h}^{-1}$ & 0.97 \\
& Worker salary & $€ \mathrm{~h}^{-1}$ & 11.50 \\
\hline & & &
\end{tabular}

\subsection{Seed Loss Evaluation}

The total harvesting seed loss (HASL) is given by the sum of the seed loss due to the inefficiency of the header to correctly collect the capitula (HESL), and the ineffectiveness of the cleaning shoe of the combine harvester to discriminate the seeds from the other portions of the processed biomass (TSL). To summarize, HESL is given by the not-threshed capitula laying on the ground or standing on plants not correctly cut by the header, and TSL corresponds to the seeds discharged from the rear of the combine harvester rather than being collected in its container. 
To estimate TSL, a tarpaulin was manually held near the combine harvester in five sample plots of $96 \mathrm{~m}^{2}$ each $(4.8 \times 20 \mathrm{~m})$ to collect the seeds lost from the sieves and straw walkers [41]. Therefore, the overall amount of material expelled by the machine was collected in the tarpaulin. Such a material was shipped to the laboratory, then weighed, and sieved to assess the amount of TSL.

To estimate HESL, 10 sample plots of $30 \mathrm{~m}^{2}$ each $(5 \times 6 \mathrm{~m})$ were randomly established in the field. All the not-threshed capitula present both on the ground and on not-cut plants were collected and put in sealed bags to be brought to the CREA-IT laboratory. Here, the previously mentioned stationary thresher PLOT 2375 was used to thresh them and collect the seeds of the capitula. Seeds were subsequently weighed to estimate HESL.

\section{Results}

The main crop features are given in Table 2. As it is possible to notice, the number of plants per hectare reached 22,667 $\mathrm{N} \mathrm{ha}^{-1}$ with an average plant height of $147 \mathrm{~cm}$. The aerial biomass was $6.25 \mathrm{Mg} \mathrm{ha}^{-1} \mathrm{FM}$, which, considering the average potential seed yield (PSY) of $1.11 \mathrm{Mg} \mathrm{ha}^{-1} \mathrm{FM}$, consisted of a harvest index (HI) of 0.20 . The seed moisture content was $5.82 \%$, while the leaves and stalks exhibited the higher moisture content: $14.08 \%$ and $44.00 \%$, respectively. The bulk density of the seeds collected was $0.644 \mathrm{Mg} \mathrm{m}^{-3} \mathrm{FM}$.

Table 2. Crop features and potential seed yield before the mechanical harvesting.

\begin{tabular}{cccc}
\hline Parameter & Measure Unit & Average & St. Dev. \\
\hline Plants per hectare & $\mathrm{N} \mathrm{ha}^{-1}$ & 22,667 & 1685 \\
\hline Plants height & $\mathrm{cm}$ & 147 & 111 \\
\hline Capitula per plant & $\mathrm{N}$ & 7.4 & 4.2 \\
\hline Height of the lower capitulum & $\mathrm{cm}$ & 126 & 13 \\
\hline Seeds content per capitulum & $\mathrm{g} \mathrm{FM}$ & 6.7 & 0.7 \\
\hline 1000-seeds weight & $\mathrm{g} \mathrm{FM}^{-3} \mathrm{FM}$ & 0.644 & 0.014 \\
\hline Bulk density of collected seed & $\mathrm{Mg} \mathrm{m}^{-3}$ & 6.17 & 1.20 \\
\hline Aerial biomass & $\mathrm{Mg} \mathrm{ha}^{-1} \mathrm{FM}$ & 6.86 \\
\hline Potential seed yield (PSY) & $\mathrm{Mg} \mathrm{ha}^{-1} \mathrm{FM}$ & 1.11 & 0.14 \\
\hline Potential seed yield (PSY) & $\mathrm{Mg} \mathrm{ha}^{-1} \mathrm{DM}$ & 1.05 & 0.13 \\
\hline Harvest index (HI) & - & 0.20 & 0.07 \\
\hline Seeds moisture & $\%$ & $5.82 \%$ & $0.03 \%$ \\
\hline Leaves moisture & $\%$ & $14.08 \%$ & $1.67 \%$ \\
\hline Stalk moisture & $\%$ & $44.00 \%$ & $15.90 \%$ \\
\hline
\end{tabular}

The combine harvester's performance is given in Table 3. The effective seed yield (ESY) resulted in $0.89 \mathrm{Mg} \mathrm{ha}^{-1}$, while the working speed of $4.92 \mathrm{~km} \mathrm{~h}^{-1}$ led to a TFC of $2.36 \mathrm{ha} \mathrm{h}^{-1}$. The EFC was $2.05 \mathrm{ha} \mathrm{h}^{-1}$ and the FE was $87.24 \%$. Moreover, the MC was estimated in $1.82 \mathrm{Mg} \mathrm{h}^{-1}$.

Table 3. Performance of the combine harvester equipped with the sunflower header.

\begin{tabular}{cccc}
\hline Parameter & Measure Unit & Average & St. Dev. \\
\hline Working speed & $\mathrm{km} \mathrm{h}^{-1}$ & 4.92 & 0.87 \\
Theoretical Field Capacity (TFC) & $\mathrm{ha} \mathrm{h}^{-1}$ & 2.36 & 0.42 \\
Effective Field Capacity (EFC) & $\mathrm{ha} \mathrm{h}^{-1}$ & 2.05 & 0.33 \\
Field Efficiency (FE) & $\%$ & $87.24 \%$ & $4.13 \%$ \\
Material Capacity (MC) & $\mathrm{Mg} \mathrm{h}^{-1}$ & 1.82 & 0.30 \\
\hline
\end{tabular}


The values reported above for the working performance led to a cost per surface unit of $69.52 € \mathrm{ha}^{-1}$, which consists of a cost per biomass unit of $86.15 € \mathrm{Mg}^{-1}$ (Table 4).

Table 4. Evaluation of the harvesting unitary costs.

\begin{tabular}{ccc}
\hline Parameter & Measure Unit & Value \\
\hline Costs per unit of time & $€ \mathrm{~h}^{-1}$ & 142.74 \\
Cost per unit of surface & $€ \mathrm{ha}^{-1}$ & 69.52 \\
Costs per unit of seed yield & $€ \mathrm{Mg}^{-1} \mathrm{FM}$ & 86.15 \\
\hline
\end{tabular}

Concerning the evaluation of the seed loss, reported in Table 5, the major part of the lost seed was related to the header (HESL), with a value of $28.72 \mathrm{~kg} \mathrm{ha}^{-1}$ corresponding to $2.58 \%$ of the PSY, while the combine harvester threshing systems (TSL) led to only $6.44 \mathrm{~kg} \mathrm{ha}^{-1}$ of the lost seed, corresponding to $0.58 \%$. Therefore, the overall harvesting loss (HASL) resulted in $35.16 \mathrm{~kg} \mathrm{ha}^{-1}$, i.e., $3.16 \%$ of PSY.

Table 5. Evaluation of the seed loss due to the header and threshing system.

\begin{tabular}{cccc}
\hline Parameter & Measure Unit & Average & St. Dev. \\
\hline Header seed loss (HESL) & $\mathrm{kg} \mathrm{ha}^{-1}$ & 28.72 & 17.13 \\
Header seed loss (HESL) & $\%$ & $2.58 \%$ & $1.54 \%$ \\
Threshing system seed loss (TSL) & $\mathrm{kg} \mathrm{ha}^{-1}$ & 6.44 & 3.20 \\
Threshing system seed loss (TSL) & $\%$ & $0.58 \%$ & $0.29 \%$ \\
Harvesting seed loss (HASL) & $\mathrm{kg} \mathrm{ha}^{-1}$ & 35.16 & - \\
Harvesting seed loss (HASL) & $\%$ & $3.16 \%$ & - \\
\hline
\end{tabular}

\section{Discussion}

Cynara has been proposed as a perennial crop for biomass production and oil seed crop due to its high adaptability throughout the Mediterranean region and its tolerance to unfavorable conditions. The plant density was $2.26 \mathrm{~m}^{-2}$ on average, which agrees with the majority of the values found in the literature, although the plant density can range from 0.5 to $16 \mathrm{~m}^{-2}$, as reported by Gherbin et al. (2001) and Raccuia et al. (2012). The higher the plant density, the better the yield [14,42]. However, it is important to underline that, in the present study, a certain variability in the mean value of the plant density was due to the undesired flooding events which were scattered on the field. This reduced the germination of the seeds and, in turn, the effective grown surface by $9 \%$ of the initial sown surface.

The aerial fresh biomass resulted in $6.25 \mathrm{Mg} \mathrm{ha}^{-1}$. This parameter, along with the seed yield, is quite sensitive to the local climate and soil conditions. Therefore, they can both remarkably vary in the Mediterranean region. In fact, the biomass yield ranged from $3.4 \mathrm{Mg} \mathrm{ha}^{-1} \mathrm{DM}$ in the dryland conditions in Spain [22], to $16.6 \mathrm{Mg} \mathrm{ha}^{-1} \mathrm{DM}$ in Romania [43], up to $27.6 \mathrm{Mg} \mathrm{ha}^{-1} \mathrm{DM}$, as reported by Ierna et al. (2012) under the irrigation regime [44]. It is important to highlight that the cardoon biomass is an interesting by-product, indeed it is suitable for bio-energy production in the form of a solid biofuel, as well as through pyrolysis and gasification [13]. However, in the present case, the biomass was chopped after seed harvesting and left on the ground to ensure the input of the organic matter in the soil [45].

Focusing on seed harvesting, the potential seed yield was $1.11 \mathrm{Mg} \mathrm{ha}^{-1} \mathrm{FM}\left(1.05 \mathrm{Mg} \mathrm{ha}^{-1}\right.$ as dry matter) and each capitulum carried $6.7 \mathrm{~g}$ of seeds on average. Curt et al. (2002) reported a seed yield of $1.3 \mathrm{Mg} \mathrm{ha}^{-1} \mathrm{DM}$ in the field test conducted in Central Spain [46], while field trials in Sicily (South Italy) showed values ranging from 0.28 to $2.61 \mathrm{Mg} \mathrm{ha}^{-1} \mathrm{DM}$ [47]. The lower seed yield value of about $0.6 \mathrm{Mg} \mathrm{ha}^{-1}$ was reported by Gominho et al. (2011) in Southern Portugal [48]. Finally, the 3-year study performed in Central Italy on marginal lands by Francaviglia et al. 2016, reported the cardoon seeds yield up to $3.69 \mathrm{Mg} \mathrm{ha}^{-1}$ [20].

The 1000-seed weight was $37.17 \mathrm{~g}$ FM on average, values higher than $30 \mathrm{~g}$ are considered valid for sowing [49]. 
A lower aerial biomass production eases the mechanical harvesting since less biomass is processed by the combine harvester which, therefore, can better discriminate the seeds from the rest of the collected biomass. Additionally, the mean plant height (from the base of the plant to the top of the first capitulum) was $147 \mathrm{~cm}$ and the lowest capitulum was positioned on average at $126 \mathrm{~cm}$ from the ground. Therefore, the capitula were usually carried in a range of just $20 \mathrm{~cm}$ from the lowest to the highest one. This pattern allowed setting the cutting bar of the combine harvester at approximately $100 \mathrm{~cm}$ from the ground with a few adjustments needed during harvesting.

The performance of the combine harvester agrees with the current literature. The EFC of $2.05 \mathrm{ha} \mathrm{h}^{-1}$ found in the present study is consistent with the EFC found in similar studies, but performed with the specific header, which reported values ranging from 1.57 to $2.10 \mathrm{ha} \mathrm{h}^{-1}$ [28-30]. In addition, the FE of $87.24 \%$ is also consistent with other tests performed on cereals harvesting, where the tested combine harvesters were all equipped with a dedicated header [38,50,51].

The harvesting cost of cardoon seeds per surface unit was $69.52 € \mathrm{ha}^{-1}$, lower than $109.00 € \mathrm{ha}^{-1}$ as reported by Francaviglia et al. 2016 [20]. However, Semerci et al. (2010 and 2019) found that the sunflower of safflower harvesting cost ranged from 57.23 to $82.11 € \mathrm{ha}^{-1}$ for sunflower seeds harvesting [52,53].

Another fundamental parameter to evaluate the suitability of a given harvesting system is yield loss, which is related to the proper machinery functioning in relation to the features of the crop. Pari et al. (2016) reported a seed loss of about $3 \% w / w$ when the cardoon seeds were harvested using a combine harvester equipped with the specific header [30]. According to our findings, a similar result can be obtained without using the specific header. In fact, only $3.2 \% w / w$ of the seed loss was found and this is consistent with the findings reported in similar studies dealing with the mechanical harvesting of other oil seeds, namely: $0.97-2.76 \% w / w$ in canola (Brassica napus L.) [54,55], about 3\% $w / w$ in safflower (Carthamus tinctorius L.) [26] and crambe (Crambe cabyssinica Hochst) [56], and 2\% w/w in sunflower [57], although reducible to less than $1 \% w / w$ if particular adjustments are applied $[58,59]$. Nevertheless, it is dutiful to underline that the specific cardoon header described by Pari et al. was specifically developed to prevent the subsequent use of a shredder to manage the left aboveground biomass [28,30]. In fact, as reported above, the cardoon biomass is suitable for bioenergy purposes [60-64] but, unfortunately, the value chain is not yet developed in such a way. Consequently, the cardoon biomass still represents a burden and cost for farmers and contractors, which refuse to invest money on specific equipment, as for instance, the ad-hoc header for the combine harvester. In this point of view, it is worthy to keep on investigating the possibility to stretch the suitability of existing machineries as much as possible.

\section{Conclusions}

Cardoon seeds have been strongly proven to be suitable for multipurpose applications and the Mediterranean region fulfils the agroecological needs of the species. The different fractions of the aboveground and belowground biomass are gaining attention worldwide from industries, among them, seeds are proven to be rich in oil suitable for the green biochemistry applications, as bioplastics.

Therefore, it is important to investigate the weaker parts of the cardoon biomass value chain in order to make it feasible and worthy for both farmers and industries. To date, several studies have been conducted to try to address the problems related to the harvesting of the seeds but, unfortunately, the modifications to the machineries were costly and not affordable to farmers and contractors.

Our findings address the problems related to the harvesting stage, which is still not fully investigated. Particularly, under two critical aspects, such as the possibility to use the already available technology and related costs. The hypothesis to use a conventional combine harvester equipped with the sunflower header is supported by our results. The machine has performed as good as the dedicated prototypes tested in the past. Additionally, the reduced production of aerial biomass experienced in the mentioned cropping regime, has eased the cleaning process carried out by the combine harvester. Clogs did not occur, and the seed loss was low. In addition, the harvesting costs are similar to those experienced in sunflower seed harvesting. 
In conclusion, the present study does not preclude the will to further improve the harvesting machinery specifically dedicated to cardoon seed harvesting but, it does provide scientific evidence to farmers, contractors, and large enterprises on the possibility to use the available technology to collect cardoon seeds efficiently.

Author Contributions: Conceptualization, F.L., W.S., and L.P.; methodology, F.L. and W.S.; data curation, F.L., W.S., and S.S.; writing—original draft preparation, F.L., W.S., and S.S.; writing—review and editing, F.L., W.S., G.M.B., and L.P.; supervision, L.P.; funding acquisition, L.P. All authors have read and agreed to the published version of the manuscript.

Funding: This research was funded by Horizon 2020 projects Panacea (grant number 773501) and Magic (grant number 727698).

Acknowledgments: The authors would like to thank Maccarese SPA (Viale Maria 423, 00057 Fiumicino, Italy) and Novamont SPA (Via G. Fauser 8, 28100 Novara, Italy) for the organization of the tests and the precious support during the trials and Sandu Lazar for the help in performing the field and laboratory tests.

Conflicts of Interest: The authors declare no conflict of interest.

\section{Abbreviations}

EFC Effective Field Capacity $\left(\right.$ ha $\mathrm{h}^{-1}$ )

FE Field Efficiency (\%)

HASL Harvesting seed loss $\left(\mathrm{kg} \mathrm{ha}^{-1}\right)$, i.e., overall loss of seeds due to harvesting

HESL Header seed loss $\left(\mathrm{kg} \mathrm{ha}^{-1}\right)$, i.e., loss due to the impact of the header on the standing plants

MC Material Capacity $\left(\mathrm{Mg} \mathrm{FM} \mathrm{h}^{-1}\right)$

PSY Potential seed yield (Mg FM ha $\left.{ }^{-1}\right)$

TFC Theoretical Field Capacity $\left(\mathrm{ha}^{-1}\right.$ )

TSL Tarpaulin seed loss $\left(\mathrm{kg} \mathrm{ha}^{-1}\right)$, i.e., seed loss due to the threshing system of the combine harvester

\section{References}

1. Samarappuli, D.; Zanetti, F.; Berzuini, S.; Berti, M.T. Crambe (Crambe abyssinica Hochst): A Non-Food Oilseed Crop with Great Potential: A Review. Agronomy 2020, 10, 1380. [CrossRef]

2. Zandi Atashbar, N.; Labadie, N.; Prins, C. Modelling and optimisation of biomass supply chains: A review. Int. J. Prod. Res. 2018, 56, 3482-3506. [CrossRef]

3. Righini, D.; Zanetti, F.; Monti, A. The bio-based economy can serve as the springboard for camelina and crambe to quit the limbo. OCL 2016, 23, D504. [CrossRef]

4. Gelfand, I.; Sahajpal, R.; Zhang, X.; Izaurralde, R.C.; Gross, K.L.; Robertson, G.P. Sustainable bioenergy production from marginal lands in the US Midwest. Nature 2013, 493, 514-517. [CrossRef]

5. Von Cossel, M.; Lewandowski, I.; Elbersen, B.; Staritsky, I.; Van Eupen, M.; Iqbal, Y.; Mantel, S.; Scordia, D.; Testa, G.; Cosentino, S.L.; et al. Marginal Agricultural Land Low-Input Systems for Biomass Production. Energies 2019, 12, 3123. [CrossRef]

6. D'Avino, L.; Di Bene, C.; Farina, R.; Razza, F. Introduction of Cardoon (Cynara cardunculus L.) in a Rainfed Rotation to Improve Soil Organic Carbon Stock in Marginal Lands. Agronomy 2020, 10, 946. [CrossRef]

7. Toscano, V.; Sollima, L.; Genovese, C.; Melilli, M.G.; Raccuia, S.A. Pilot plant system for biodiesel and pellet production from cardoon: Technical and economic feasibility. Acta Hortic. 2016, 1147, 429-442. [CrossRef]

8. Scordia, D.; Cosentino, S. Perennial Energy Grasses: Resilient Crops in a Changing European Agriculture. Agriculture 2019, 9, 169. [CrossRef]

9. Vasilakoglou, I.; Dhima, K. Potential of two cardoon varieties to produce biomass and oil under reduced irrigation and weed control inputs. Biomass Bioenergy 2014, 63, 177-186. [CrossRef]

10. Mauro, R.P.; Sortino, O.; Pesce, G.R.; Agnello, M.; Lombardo, S.; Pandino, G.; Mauromicale, G. Exploitability of cultivated and wild cardoon as long-term, low-input energy crops. Ital. J. Agron. 2015, 10, 44-46. [CrossRef]

11. Velez, Z.; Campinho, M.A.; Guerra, Â.R.; García, L.; Ramos, P.; Guerreiro, O.; Felício, L.; Schmitt, F.; Duarte, M. Biological characterization of Cynara cardunculus L. Methanolic extracts: Antioxidant, anti-proliferative, anti-migratory and anti-angiogenic activities. Agriculture 2012, 2, 472-492. [CrossRef] 
12. Pappalardo, H.D.; Toscano, V.; Puglia, G.D.; Genovese, C.; Raccuia, S.A. Cynara cardunculus L. as a Multipurpose Crop for Plant Secondary Metabolites Production in Marginal Stressed Lands. Front. Plant Sci. 2020, 11, 240. [CrossRef]

13. Gominho, J.; Curt, M.D.; Lourenço, A.; Fernández, J.; Pereira, H. Cynara cardunculus L. as a biomass and multi-purpose crop: A review of 30 years of research. Biomass Bioenergy 2018, 109, 257-275. [CrossRef]

14. Raccuia, S.A.; Gallo, G.; Melilli, M.G. Effect of plant density on biomass and grain yields in Cynara cardunculus var. altilis cultivated in Sicily. Acta Hortic. 2012, 942, 303-308. [CrossRef]

15. Fernández, J.; Manzanares, P. Cynara cardunculus L., a new crop for oil, paper pulp and energy. In Proceedings of the 5th European Conference on Biomass for Energy and Industry, Lisbon, Portugal, 9-13 October 1989; Elsevier Applied Science: London, UK, 1990; pp. 1184-1189.

16. Sengo, I.; Gominho, J.; D'Orey, L.; Martins, M.; D'Almeida-Duarte, E.; Pereira, H.; Ferreira-Dias, S. Response surface modeling and optimization of biodiesel production from Cynara cardunculus oil. Eur. J. Lipid Sci. Technol. 2010, 112, 310-320. [CrossRef]

17. Alexandre, A.; Dias, A.M.A.; Seabra, I.J.; Portugal, A.; De Sousa, H.C.; Braga, M.E.M. Biodiesel obtained from supercritical carbon dioxide oil of Cynara cardunculus L. J. Supercrit. Fluids 2012, 68, 52-63. [CrossRef]

18. Raccuia, S.A.; Piscioneri, I.; Sharma, N.; Melilli, M.G. Genetic variability in Cynara cardunculus L. domestic and wild types for grain oil production and fatty acids composition. Biomass Bioenergy 2011, 35, 3167-3173. [CrossRef]

19. Grammelis, P.; Malliopoulou, A.; Basinas, P.; Danalatos, N.G. Cultivation and characterization of Cynara cardunculus for solid biofuels production in the Mediterranean region. Int. J. Mol. Sci. 2008, 9, 1241-1258. [CrossRef]

20. Francaviglia, R.; Bruno, A.; Falcucci, M.; Farina, R.; Renzi, G.; Russo, D.E.; Sepe, L.; Neri, U. Yields and quality of Cynara cardunculus L. wild and cultivated cardoon genotypes. A case study from a marginal land in Central Italy. Eur. J. Agron. 2016, 72, 10-19. [CrossRef]

21. Gominho, J.; Lourenço, A.; Curt, M.; Fernández, J.; Pereira, H. Characterization of hairs and pappi from Cynara cardunculus capitula and their suitability for paper production. Ind. Crops Prod. 2009, 29, 116-125. [CrossRef]

22. Fernández, J.; Curt, M.D.; Aguado, P.L. Industrial applications of Cynara cardunculus L. for energy and other uses. Ind. Crops Prod. 2006, 24, 222-229. [CrossRef]

23. Angelini, L.G.; Ceccarini, L.; Nassi o Di Nasso, N.; Bonari, E. Long-term evaluation of biomass production and quality of two cardoon (Cynara cardunculus L.) cultivars for energy use. Biomass Bioenergy 2009, 33, 810-816. [CrossRef]

24. Lourenço, A.; Neiva, D.M.; Gominho, J.; Curt, M.D.; Fernández, J.; Marques, A.V.; Pereira, H. Biomass production of four Cynara cardunculus clones and lignin composition analysis. Biomass Bioenergy 2015, 76, 86-95. [CrossRef]

25. Fernández, J.; Hidalgo, M.; Del Monte, J.P.; Curt, M.D. Aprovechamiento del cardo (Cynara cardunculus L.) para la producción de biomasa lignocelulósica, aceite y forraje verde. Itea. Prod. Veg. 1996, 17, 40-56.

26. Pari, L.; Latterini, F.; Stefanoni, W. Herbaceous Oil Crops, a Review on Mechanical Harvesting State of the Art. Agriculture 2020, 10, 309. [CrossRef]

27. Fernandez, J.; Pari, L.; García Müller, M.; Marquez, L.; Fedrizzi, M.; Curt, M.D. Strategies for the mechanical harvesting of Cynara. In Proceedings of the 15th European Biomass Conference \& Exhibition, Berlin, Germany, 7-11 May 2007.

28. Pari, L.; Fedrizzi, M.; Gallucci, F. Cynara cardunculus exploitation for energy applications: Development of a combine head for thesing and concurrent residues collecting and utilization. In Proceedings of the 16th European Biomass Conference \& Exhibition, Valencia, Spain, 2-6 June 2008.

29. Pari, L.; Sissot, F.; Giannini, E. European Union Research Project Biocard: Mechanization Activities Results. In Proceedings of the Technology and Management to Increase the Efficiency in Sustainable Agricultural Systems, Rosario, Argentina, 1-4 September 2009.

30. Pari, L.; Alfano, V.; Acampora, A.; Del Giudice, A.; Scarfone, A.; Sanzone, E. Harvesting and Separation of Different Plant Fractions in Cynara cardunculus L. In Perennial Biomass Crops for a Resource-Constrained World; Barth, S., Murphy-Bokern, D., Kalinina, O., Taylor, G., Jones, M., Eds.; Springer: Berlin/Heidelberg, Germany, 2016; pp. 261-271. ISBN 978-3-319-44529-8.

31. Pari, L.; Del Giudice, A.; Pochi, D.; Gallucci, F.; Santangelo, E. An innovative flexible head for the harvesting of cardoon (Cynara cardunculus L.) in stony lands. Ind. Crops Prod. 2016, 94, 471-479. [CrossRef] 
32. Pari, L.; Alfano, V.; Mattei, P.; Santangelo, E. Pappi of cardoon (Cynara cardunculus L.): The use of wetting during the harvesting aimed at recovering for the biorefinery. Ind. Crops Prod. 2017, 108, 722-728. [CrossRef]

33. Zaffrani Sunflower Harvesting Kit. Available online: http://www.zaffrani.it/it/accessori_kit_adattamentoi_ testata/ (accessed on 3 December 2020).

34. Reith, S.; Frisch, J.; Winkler, B. Revision of the working time classification to optimize work processes in modern agriculture. Chem. Eng. Trans. 2017, 58, 121-126. [CrossRef]

35. NSAI ISO 18134-2:2017 Solid Biofuels—Determination of Moisture Content-Oven Dry Method-Part 2: Total Moisture-Simplified Method. Available online: https://www.iso.org/standard/71536.html (accessed on 6 July 2020).

36. ISO 17828:2015 ISO 17828:2015 Solid Biofuels-Determination of Bulk Density. Available online: https: //www.iso.org/obp/ui/\#iso:std:iso:17828:ed-1:v1:en (accessed on 23 July 2020).

37. Assirelli, A.; Pignedoli, S. Costo di esercizio delle macchine agricole. Cent. Ric. Prod. Anim. 2005, 5, 1-10.

38. Suardi, A.; Stefanoni, W.; Bergonzoli, S.; Latterini, F.; Jonsson, N.; Pari, L. Comparison between Two Strategies for the Collection of Wheat Residue after Mechanical Harvesting: Performance and Cost Analysis. Sustainability 2020, 12, 4936. [CrossRef]

39. Banca d'Italia Banca d'Italia Lending Rate. Available online: https://www.bancaditalia.it/ (accessed on 11 July 2020).

40. American Society of Agricultural Engineers. American Society of Agricultural Engineers ASAE Standard D497.4: Agriculture Machinery Management Data; American Society of Agricultural Engineers: St. Joseph, MI, USA, 2003; pp. 373-380.

41. Stefanoni, W.; Latterini, F.; Ruiz, J.P.; Bergonzoli, S.; Attolico, C.; Pari, L. Mechanical Harvesting of Camelina: Work Productivity, Costs and Seed Loss Evaluation. Energies 2020, 13, 5329. [CrossRef]

42. Gherbin, P.; Monteleone, M.; Tarantino, E. Five year evaluation on cardoon (Cynara cardunculus L. var. altilis) biomass production in a Mediterranean environment. Ital. J. Agron. 2001, 5, 11-19.

43. Bolohan, C.; Marin, D.I.; Mihalache, M.; Ilie, L.; Oprea, A.C. Research on Cynara cardunculus L. species under the conditions of southeastern Romania area. Sci. Pap. Ser. A Agron. 2013, 56, 429-432.

44. Ierna, A.; Mauro, R.P.; Mauromicale, G. Biomass, grain and energy yield in Cynara cardunculus L. as affected by fertilization, genotype and harvest time. Biomass Bioenergy 2012, 36, 404-410. [CrossRef]

45. Santhi, C.; Srinivasan, R.; Arnold, J.G.; Williams, J.R. A modeling approach to evaluate the impacts of water quality management plans implemented in a watershed in Texas. Environ. Model. Softw. 2006, 21, 1141-1157. [CrossRef]

46. Curt, M.D.; Sánchez, G.; Fernández, J. The potential of Cynara cardunculus L. for seed oil production in a perennial cultivation system. Biomass Bioenergy 2002, 23, 33-46. [CrossRef]

47. Raccuia, S.A.; Melilli, M.G. Biomass and grain oil yields in Cynara cardunculus L. genotypes grown in a Mediterranean environment. Field Crops Res. 2007, 101, 187-197. [CrossRef]

48. Gominho, J.; Lourenço, A.; Palma, P.; Lourenço, M.E.; Curt, M.D.; Fernández, J.; Pereira, H. Large scale cultivation of Cynara cardunculus L. for biomass production-A case study. Ind. Crops Prod. 2011, 33, 1-6. [CrossRef]

49. Archontoulis, S.V.; Danalatos, N.G.; Struik, P.C.; Vos, J.; Yin, X. Agronomy of Cynara cardunclulus growing on an aquic soil in central Greece. In Proceedings of the International Conference on Agricultural Engineering, Crete, Greece, 23-25 June 2008.

50. Suardi, A.; Stefanoni, W.; Alfano, V.; Bergonzoli, S.; Pari, L. Equipping a Combine Harvester with Turbine Technology Increases the Recovery of Residual Biomass from Cereal Crops via the Collection of Chaff. Energies 2020, 13, 1572. [CrossRef]

51. Suardi, A.; Saia, S.; Stefanoni, W.; Gunnarsson, C.; Sundberg, M.; Pari, L. Admixing Chaff with Straw Increased the Residues Collected without Compromising Machinery Efficiencies. Energies 2020, 13, 1766. [CrossRef]

52. Semerci, A.; Kaya, Y. The Components of Production Cost in Sunflower and its Relationships with Input Prices. Int. Rev. Appl. Econ. 2010, 5, 139-146.

53. Semerci, A. Cost analysis of oily sunflower production: The case of Tekirdag province, Turkey. Custos e Agronegocio 2019, 15, 167-191.

54. Asoodar, A.M.; Izadinia, Y.; Desbiolles, J. Benefits of harvester front extension in reducing canola harvest losses. Int. Agric. Eng. J. 2012, 21, 32-37. 
55. Pari, L.; Assirelli, A.; Suardi, A.; Civitarese, V.; Del Giudice, A.; Costa, C.; Santangelo, E. The harvest of oilseed rape (Brassica napus L.): The effective yield losses at on-farm scale in the Italian area. Biomass Bioenergy 2012, 46, 453-458. [CrossRef]

56. Reginato, P. Colheita Mecanizada de Sementes de Crambe (Crambe abyssinica L.) no Cerrado sul Mato Grossense. Ph.D. Thesis, Universidade Federal da Grande Dourados, Dourados, Brazil, 2014.

57. Chaplygin, M.; Bespalova, O.; Podzorova, M. Results of tests of devices for sunflower harvesting in economic conditions. E3S Web Conf. 2019, 126, 1-7. [CrossRef]

58. Startsev, A.S.; Demin, E.E.; Danilin, A.V.; Vasilyev, O.A.; Terentyev, A.G. Results of the production test of sunflower harvesting attachment with an auger reel. IOP Conf. Ser. Earth Environ. Sci. 2020, 433. [CrossRef]

59. Shaforostov, V.D.; Makarov, S.S. The header for a breeding plot combine for sunflower harvesting. Acta Technol. Agric. 2019, 22, 60-63. [CrossRef]

60. Gil, M.; Arauzo, I.; Teruel, E.; Bartolomé, C. Milling and handling Cynara cardunculus L. for use as solid biofuel: Experimental tests. Biomass Bioenergy 2012, 41, 145-156. [CrossRef]

61. Encinar, J.M.; Gonzalez, J.F.; Rodriguez, J.J.; Tejedor, A. Biodiesel fuels from vegetable oils: Transesterification of Cynara cardunculus L. oils with ethanol. Energy Fuels 2002, 16, 443-450. [CrossRef]

62. Encinar, J.M.; Gonzalez, J.F.; Gonzalez, J. Fixed-bed pyrolysis of Cynara cardunculus L. Product yields and compositions. Fuel Process. Technol. 2000, 68, 209-222. [CrossRef]

63. Ballesteros, M.; Negro, M.J.; Manzanares, P.; Ballesteros, I.; Sáez, F.; Oliva, J.M. Fractionation of Cynara cardunculus (cardoon) biomass by dilute-acid pretreatment. In Applied Biochemistry and Biotecnology; Springer: Berlin/Heidelberg, Germany, 2007; pp. 239-252.

64. Kalamaras, S.D.; Kotsopoulos, T.A. Anaerobic co-digestion of cattle manure and alternative crops for the substitution of maize in South Europe. Bioresour. Technol. 2014, 172, 68-75. [CrossRef] [PubMed]

Publisher's Note: MDPI stays neutral with regard to jurisdictional claims in published maps and institutional affiliations. 